\title{
Analysis of Factors that Form Teacher's Discipline Behavior in Public Junior High School
}

\author{
Amalinda Dwi Futesna \\ Department of Educational Administration \\ Universitas Negeri Malang, Indonesia \\ amalinda.d.futesna@gmail.com
}

Raden Bambang Sumarsono

Department of Educational Administration

Universitas Negeri Malang, Indonesia

raden.bambang.fip@um.ac.id

\author{
Bambang Budi Wiyono \\ Department of Educational Administration \\ Universitas Negeri Malang, Indonesia \\ bambang.budi.fip@um.ac.id \\ Achmad Supriyanto \\ Department of Educational Administration \\ Universitas Negeri Malang, Indonesia \\ a.supriyanto.fip@um.ac.id
}

\begin{abstract}
The objectives of this study are to: (1) describe the discipline level of teachers in State Junior High Schools; (2) find out the factors that form the discipline behavior of teachers in State Junior High Schools; (3) find out the differences in the discipline level of male teachers and female teachers; and (4) knowing differences in the level of teacher discipline based on employment status. This study uses a quantitative method with a descriptive correlation research design and uses explanatory and descriptive analysis techniques. This study also uses a prerequisite test which includes homogeneity test, normality test, and independent sample t-test. The population in this study was 1,651 teachers with samples used by 174 teachers. Sampling collection and determination techniques using Sampling and Proportional Sampling Areas (clusters). The results of this study indicate that: (1) the discipline level of junior high school teachers in Jombang is in the moderate category; (2) new factors formed there are three factors including factors of encouragement/support, environmental factors and school policy factors; (3) there is no difference in level discipline of male teachers with female teachers; and (4) there is no difference in the discipline level between civil servant teachers and Non civil servants.
\end{abstract}

Keywords: discipline factors, employment status, teacher

\section{INTRODUCTION}

Teacher is the main actor in the education program in school in order to achieve educational goals as expected. Teachers are educators who have the duty and responsibility to educate, guide, train, assess, and evaluate students, so that the students act in accordance with the norms, values and rules that apply (Banawi \& Arifin, 2012). From its role as a very valuable and very important educator, the teachers are required to have a high ability and understanding of competence as a teacher/educator.

The school environment requires educators who have behaviors that can be followed by their students, like discipline behavior. According to Aini (2017), discipline does not only occur to students, but discipline can also occur to the teacher, all teachers must comply with the rules that apply at school and be responsible for their duties. Discipline is the most important thing for a teacher. Without the discipline of a teacher, it cannot be named as a teacher. Because the teacher is determined as generous, wise, and always disciplined person. Especially, in the world of education, teacher's discipline is preferred because it can affect the teacher's work productivity.

Factors of discipline behavior are factors that originate both within individuals and from outside individuals to support teacher's discipline. According to Unaradjan (2003), there are internal (psychological and physical) factors and external factors (family, school environment, and society), whereas according to Hasibuan (1994), indicators that influence the discipline of an organization include: (1) exemplary leadership, (2) remuneration, (3) goals and abilities, (4) sanctions and penalties, and (5) inherent supervision. And according to
Lewin (Helmi, 1996), the factors that form teacher's discipline are personality factors and environmental factors.

The level of teacher's discipline can be seen based on an employment status (a civil servant teacher (PNS) / not a civil servant teacher (Non-PNS)). In Indonesia educators / teachers have various types of employment status, namely civil servant educators / teachers or civil servants (PNS) and not a civil servant teacher (non-PNS) teachers, and recently there is a new status named as 'not yet certified'. But for educators with different employment status, they have very far comparisons, both in differences and similarities. Work experience and salary or income are the differences between them (Nastiti, 2016).

PNS teachers and Non PNS in public schools or private schools also have differences in the discipline level, it can be said that public schools are definitely superior to private schools. But for the level of teacher's discipline in private school, it is more discipline than public schools, because if the private school teacher wants to skip the class, or be late coming to school they might be fired or reduced salary. While for public schools, even though the teacher is absent or late to come, it is not possible to be dismissed because they are very neat in administration, but the practice is still a mess (Wijaya, 2018).

\section{METHOD}

The method used in this study is a quantitative method. The purpose of using a quantitative approach is to make changes to the surrounding environment through 
experiments that will produce laws, regulations and principles that exist in the real world (Ulfatin, 2015). This study implements a descriptive research design and correlation, also uses a prerequisite test which includes normality test, homogeneity test, and independent sample t-test. This method aims to determine the level of teachers' discipline, both male and female teachers. PNS and Non-PNS teachers, and to find out new factors resulting from rotation from existing factors.

The population of this study were all teachers of junior high school in Jombang Regency, they are 1,649 teachers. Samples from this study were twenty (20) junior high schools/middle schools in Jombang Regency, they are 174 teachers. The instrument of data collection used in this study is a questionnaire containing statement items, 47 items. The analysis techniques used in this study are explanatory theory analysis techniques and descriptive analysis using SPSS (Statistic Package for Social Science) for Windows version 16.0. The research instrument used in this study is a questionnaire. Data analysis used in this study are explanatory data analysis and descriptive data analysis. Data analysis are used to process numbers obtained from raw scores into a score that is easy to read and conclude (Wiyono, 2007).

\section{RESULTS}

\section{Levels of Teachers' Discipline in Junior High School}

The description of the level of teachers' discipline in SMPN Jombang Regency can be described as follows. 67 respondents $(38.5 \%)$ are in the low category, 83 respondents $(47.7 \%)$ are in the level of medium category, and 24 respondents $(13.8 \%)$ are in the level of high category. As an illustration of the level of teachers discipline can be seen in Table 1 .

Table 1

The Level of Teacher's Discipline

\begin{tabular}{|c|c|c|c|c|}
\hline No & Criteria & Interval & Frequency & $\begin{array}{c}\text { Presentage } \\
(\%)\end{array}$ \\
\hline 1. & Low & $130-146$ & 67 & 38.5 \\
\hline 2. & Medium & $147-163$ & 83 & 47.7 \\
\hline 3. & High & 164-180 & 24 & 13.8 \\
\hline \multicolumn{3}{|c|}{ Total } & 174 & 100 \\
\hline
\end{tabular}

Based on the mean (average) variable of the teachers' discipline in Jombang Regency, it obtained the results of 150.66 , it can be concluded that the teacher's discipline of Junior High School (SMP) Negeri in Jombang Regency is found at 147-163 intervals, which means that it is in the medium category.

\section{Forming Factors of Discipline Behavior}

Based on the factor analysis test conducted using SPSS for Windows version 16.0, it produces and finds 3 groups of forming factors of discipline behavior that can be seen in Table 2. The three groups include, encouragement/support factors, environmental factors and school policy factors by the indicators obtained by the school environment, goals and abilities, personality, environment (family and community), remuneration (salary/welfare), physical condition, sanctions and punishments, work environment, inherent supervision, psychological condition and exemplary leadership.
Table 2

Results of Factors Analysis

\begin{tabular}{|c|l|c|}
\hline & \multicolumn{1}{|c|}{ Factor } & \% Variance \\
\hline 1 & Encouragement/Support factors & 21.167 \\
\hline 2 & Environmental factors & 5.536 \\
\hline 3 & School policy factors & 5.010 \\
\hline & & 31.713 \\
\hline
\end{tabular}

Based on Table 2, the factor of encouragement / support has the highest level of variance because almost all items of statement are included in that factor. The variance factor of the encouragement/support factor is $21.167 \%$. Environmental factors occupy the second position with a value of $5.536 \%$. And the last factor is the school policy factor with a value of $5.010 \%$.

Table 3

Ranking Indicator of Acquiring Factor Analysis Results

\begin{tabular}{|c|c|c|}
\hline & Indicator & $\begin{array}{c}\text { Number of } \\
\text { Factor Loads }\end{array}$ \\
\hline 1. & School environment & 3.395 \\
\hline 2. & Goals and abilities & 3.063 \\
\hline 3. & Personality & 2.593 \\
\hline 4. & Environment (family and community) & 2.189 \\
\hline 5. & Remuneration (salary/welfare) & 1.818 \\
\hline 6. & Physical condition & 1.567 \\
\hline 7. & Sanctions and punishments & 1.565 \\
\hline 8. & Work environment & 1.307 \\
\hline \multirow[t]{2}{*}{9.} & Inherent supervision & 1.056 \\
\hline & Psychological condition & 1.017 \\
\hline 11 & Exemplary leadership & 0.865 \\
\hline & Total & 20.435 \\
\hline
\end{tabular}

The dominant indicator is the indicator that most obtained the load values from the statement items in each of these indicators. Table 3. It provides details on the number of factor load values for each indicator. Based on Table 3, the school environment indicators have the highest level of load value of the factors in the formation of teacher's discipline in SMPN Jombang Regency which is equal to 3.395 , because the 47 points of the statement, as many as 6 items of statements show a connection with a teacher in bringing character in him.

\section{Differences in the Level of Teacher's Discipline based on Staff Status}

Based on the results of the analysis using the Independent Sample t-test, it obtained that the discipline level between PNS teachers and Non-PNS teachers has a significance value of $0.628>0.05$, which means that there is no difference in the discipline level between PNS teachers and Non-PNS teachers.

But, if you look at the mean (average) discipline level between PNS teachers and Non-PNS teachers, PNS teachers have a higher discipline level than Non-PNS teachers with a value of 150.91 for PNS teachers and 149.66 for Non-PNS teachers. The results of data analysis are presented in Table 4

\section{DISCUSSION}

\section{Level of Teacher's Discipline in Junior High Schools in Jombang Regency}

Based on the results, it obtained from the calculation of the statistics of teacher's discipline in Jombang Regency is in the medium category. This can be interpreted that the teachers in SMPN Jombang Regency 
has a fairly good discipline level. This situation shows that the teacher's discipline in Jombang must be further enhanced. In accordance with the opinion of Pridjodarminto (1994), the level of teacher's discipline, teachers in SMPN Jombang must cover the following aspects in order to achieve a very good discipline level, and if the teacher's discipline is good, it will have a good impact on the school. If these aspects are not met, then the level of teacher discipline is difficult to increase.

Table 4

Results of t-Test based on Staff Status

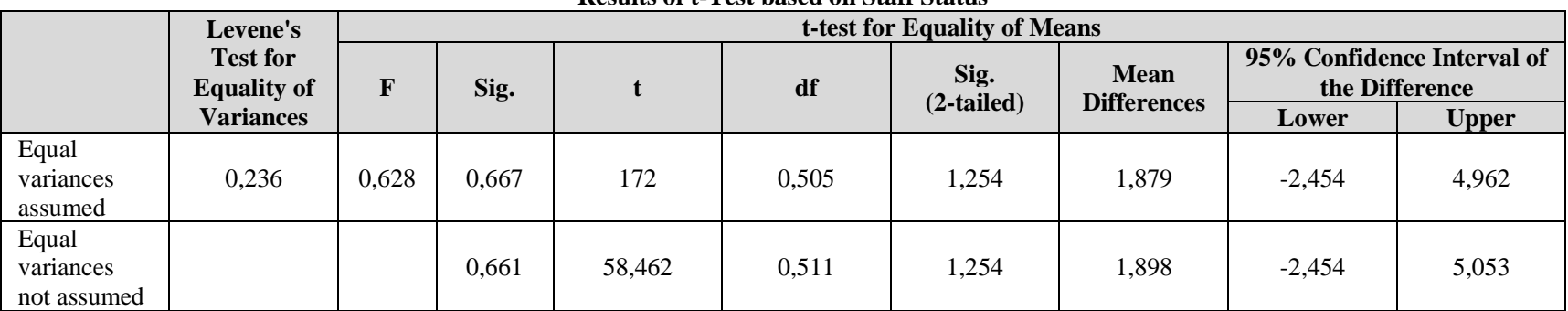

There are three aspects that shape or form the discipline level according to Pridjodarminto (1994) is: (1) mental attitude is an orderly attitude and obedience from the results of character and mind control; (2) attitudes and norms that can foster a good understanding of the rules as a condition for achieving success; and (3) showing behavior with sincerity, to obey all things in an orderly manner.

\section{Forming Factors of Middle School Teacher's Discipline Behavior in Jombang regency}

Based on the Load value that be seen in the matrix component, it identified 3 factors and has been divided into several indicators. New factors that are formed from the results of factor analysis include the factors of encouragement/support, environmental factors and school policy factors. With new indicators that include, the school environment, goals and abilities, personality, environment (family and community), remuneration (salary/welfare), physical health, sanctions and punishments, work environment, inherent supervision, psychological condition, and exemplary leadership.

This is different from the results of the research presented by Ayu, et al. (2016) which the factors that form teacher's discipline are factors of leadership policy, factors of lack of self-awareness, factors of school conditions and infrastructure, and factors of distance between residence and school. This study only discusses the factors that form teacher's discipline in general, the factors that form teacher's discipline must be reviewed in more detail, so that they can be used as a reference for them to improve discipline.

The results of other studies according to Rahayu, et al (2014) mentioned that factors originally come from the inside of the teacher itself are the dominant factors that can form discipline behavior. These factors include the character of the teacher, professional work, creativity, productivity, motivation, and teacher education. This is different from the research on the analysis of forming factors of teacher's discipline behavior in SMPN Jombang, that the most dominant factor in forming teacher's discipline behavior is the factor of encouragement/support. In the formation of teacher's discipline is not only a factor from within the teacher, but also factors from outside the teacher are very influential on improving teacher discipline.

\section{Level of Teacher's Discipline based on Gender}

Based on the independent t-test, the discipline level between male teachers and female teachers has a significance value of $0.748>0.05$, which means there is no difference in the discipline level between male teachers and female teachers. But if you look at the value of the average discipline level between male teachers and female teachers. Female teachers have a higher discipline level than male teachers with values of 151.42 for female teachers and 150.11 for male teachers. This is in accordance with the opinion of Angraeni (2007) who explains that generally women have longer age than men, their endurance is stronger, and fewer deaths of female infants than male infants. The implication is that they can work greater than men. In general, women are more diligent, resilient and have stamina better than men. However, in work environment, they are considered incompetent or unable to do so. Their personality is less creative, less competitive, not independent, subjective, less ambitious, more passive to lack of confidence.

If you see the discipline level of the teacher based on job satisfaction, with the results of analysis using t-test, it obtained $t$ value of 3.343 with $p<0.01$ and the average male leadership job satisfaction is 143.652 and female leadership job satisfaction is 128.880 . Thus, male leadership job satisfaction is higher than female leadership, which means that there is a very significant difference in job satisfaction between men's leadership and women's leadership. Leaders have an important role for the career development of their employees. The existence of a leader is highly prioritized in an organization or educational institution, because a leader is the backbone for organizational development in order to achieve an organizational goal (Kusumawati, 2006).

\section{Discipline Level based on Staff Status}

Based on the independent Sample t-test that discipline level between PNS teachers and Non-PNS teachers has a significance value of $0.628>0.05$ which means there is no difference in the discipline level of PNS teachers and Non PNS teachers. But, if you look at the value of the average discipline level between PNS teachers and Non-PNS teacher, PNS teachers have a higher discipline level than Non-PNS teachers with a value of 150.91 for PNS teachers and 149.66 for NonPNS teachers. This is similar with Pratiwi (2015) opinion 
which explains that based on the results of the independent t-test calculation (3.093) the significance is 0.003 , the results show that the difference in the discipline of certified teachers is higher than the teacher who has not been certified. Which means there is a significant difference of teacher's discipline level between teachers who have been certified and teachers who have not yet been certified.

The results of other studies according to Andani (2016) about "Differences of Work Motivation and Discipline in PNS Teacher and Non-PNS Teachers in Surabaya State Middle Schools", based on the t-test, two independent samples on the $\mathrm{H} 0$ on work motivation variable are accepted which have a probability value of 0.763 , which means probability ( $\mathrm{sig}$ ) $>0.05$, which is $0.763>0.05$. It can be concluded that there are no significant differences between PNS and Non-PNS teachers in West Surabaya State Middle Schools, because Non-PNS teachers do not go to school every day compared to PNS teachers who are in school every day and are accustomed to obeying and implementing applicable rules and norms. The discipline is only about time, work assignments, attitudes and behavior. Lack of discipline for official duties and discipline in serving the community. The research found that the average work discipline of Non-PNS teachers was 98.10 and the scores of PNS teachers was 98.56, so it was concluded that discipline level of PNS teachers was higher than NonPNS teachers in West Surabaya Middle Schools.

Based on the discipline level, when it is viewed from teacher performance, there were also no significant differences between PNS teachers and Non-PNS teachers. This can be seen by Saadah and et al. (2018) entitled "Comparative Study on the Differences between PNS teachers' Performance and Non-PNS Teacher's Performance (Study in Middle School in Singaraja City)" that based on a significance value of $0.190>0.05$ and a $t$ value of 2,348, the hypothesis in this study was rejected, which means there is no significant difference in the performance of PNS teachers and Non-PNS teachers (honorary) status. Furthermore, based on the results of the descriptive analysis, it can be concluded that teachers with civil servant status/PNS and non-civil servant/NonPNS status both have empirical meanings of performance scales in the high category.

\section{CONCLUSION}

Based on the results of the study, it can be concluded: (1) the level of teacher's discipline in Middle Schools in Jombang Regency is in the moderate category, it can be categorized into low category as 67 respondents or $38.5 \%$, while 83 respondents or $47.7 \%$ in the moderate category, and 24 respondents or $14 \%$ is in the high category, (2) the factors formed in this study after doing the analysis are: (a) encouragement/support factors, (b) environmental factors and (c) school policy factors. Indicators formed after doing factor analysis include: (a) school environment, (b) goals and abilities, (c) personality, (d) environment (family and community), (e) remuneration (salary/welfare), (f) physical condition, (g) sanctions and penalties, (h) work environment, (i) inherent supervision, (j) psychological condition, (k) exemplary leadership; (3) the most dominant factor in the formation of discipline in junior high school teachers in Jombang is a factor of encouragement/support. And the most dominant indicator in the formation of teacher's discipline is the school environment; (4) discipline level between male teachers and female teachers has a significance value of $0.748>0.05$ which means there is no difference in the discipline level between male teachers with female teachers; and (5) the discipline level between PNS teachers and Non-PNS teachers has a significance value of $0.628>0.05$ which means that there is no difference in discipline level between PNS teachers and Non-PNS teachers.

\section{REFERENCES}

[1] Aini, S. 2017. Pengaruh Kedisiplinan Guru terhadap Karakter Siswa dalam Belajar di Tsanawiyah ALWashliyah Ismailiyah No 82. Medan. Retrieved 2 July 2019, from http://repository.uinsu.ac.id/2747/1/Skripsi\%20SYARIFA H\%20AINI.pdf

[2] Andani, R.T. 2016. Perbedaan Motivasi danisiplin Kerja Pada Guru PNS dan Bukan PNS di SMP Negeri seSurabaya Barat. Retrieved 2 July 2019, from http://jurnalmahasiswa.unesa.ac.id/index.php/inspirasimanajemen-pendidikan/article/download/14610/13260.

[3] Anggraeni, A. L. 2017. Analisis Perbedaan Tingkat Disiplin Kerja PNS Sebelum dan Sesudah Implementasi Peraturan Bupati Nomor 11 Tahun 2015. Retrieved 2 July 2019, from http://repository.usd.ac.id/13193/2/132214084_full.pdf.

[4] Ayu, P. M, Buchari, N., \& Isnaini. 2018. Faktor-Faktor Yang Mempengaruhi Kedisiplinan Guru Di Smp Negeri 3 Mapat Tunggul Selatan Kabupaten Pasaman. Retrieved 2 July 2019, from http://jim.stkip-pgrisumbar.ac.id/jurnal/download/7321\&sa.

[5] Banawi, \& Arifin, M. 2012. Etika dan Profesi Kependidikan. Jogyakarta: Ar-Ruzz Media.

[6] Hasibuan, M. S. P. 1994. Manajemen Sumber Daya Manusia, Dasar dan Kunci Keberhasilan. Jakarta: CV Haji Masagung.

[7] Helmi, A. F. 1996. Disiplin Kerja. Retrieved 2 July 2019, from http:/ http://avin.staff.ugm.ac.id/data/jurnal/disiplinkerja_avin.p df.

[8] Kusumawati, D.K. 2006 Hubungan antara Persepsi terhadap Kepemimpinan Transformasional dengan Motivasi Mengembangkan Karir. Yogyakarta: Fakultas Psikologi Universitas Gadjah Mada Yogyakarta.

[9] Nastiti, S.M. 2016. Perbedaan Kinerja Guru Berdasarkan Status Kepegawaian PNS dan Non PNS Di SMA Negeri Se Kabupaten Rembang. Retrieved 2 July 2019, from https://lib.unnes.ac.id/29068/1/3401412144.pdf.

[10] Pratiwi, N, A. 2015. Studi Komparasi Disiplin Kerja Guru Sekolah Dasar Negeri yang Belum dan Sudah Bersertifikasi di Wilayah Kecamatan Tapung Hulu Kampar. Hanata Widya, 4(3), 1-9.

[11] Prijodarminto, S. 1993. Disiplin Kiat Menuju Sukses. Jakarta: PT Pradnya Pramita.

[12] Rahayu, S., Sutama, \& Narimo, S. 2014. Kepemimpinan Kepala Sekolah dan Kedisiplinan Guru SMPN Kota Surakarta. Jurnal Manajemen Pendidikan, 9(2): 97-107.

[13] Sa'adah, N., Yudana, I. M., \& Sunu, I. K. G. A. 2017. Studi Komparatif tentang Perbedaan Kinerja Guru Pkn Pns Dengan Non Pns (Studi pada SMP di Kota Singaraja). Jurnal Kewarganegaraan, 8(2): 1-10. 
[14] Ulfatin, N. 2015. Metodologi Penelitian Kualitatif di Bidang Pendidikan: Teori dan Aplikasinya. Malang: Media Nusa Creative

[15] Unaradjan, D. 2003. Manajemen Disiplin. Jakarta: PT Gramedia.

[16] Wijaya, A. 2018. Perbedaan Yang Signifikan Antara Sekolah Negeri dan Sekolah Swasta. Retrieved 2 July
2019, from https://id.quora.com/Apa-perbedaan-yangsignifikan-antara-sekolah-negeri-dan-sekolah-swasta.

[17] Wiyono, B. B. 2007. Metodologi Penelitian Kuantitatif, Kualitattif dan Action Reseach. Malang: Fakultas Ilmu Pendidikan Universitas Negeri Malang. 